\title{
Creativity Skill Proses in Project Based Learning: A Case Study of Distance Learning in Pacitan
}

DOI: https://doi.org/10.47175/rielsj.v1i2.82

\author{
| V. Ardhyantama ${ }^{1}$ | \\ ${ }^{1}$ Elementary School Education, \\ STKIP PGRI Pacitan \\ ${ }^{2}$ Elementary School Education, \\ STKIP Al Hikmah Surabaya \\ ${ }^{1}$ vit.10276@gmail.com \\ slamet.10050@gmail.com
}

\begin{abstract}
Learning creativity skill is important for students. Distance learning during the Covid-19 period is the best option for study. However, students' needs among cognitive, affective, psychomotor and various skills need to be well accommodated. This study aims to describe the process of creativity in project-based learning in distance learning. The research subjects were 10 elementary school education students grade 2nd. The learning project was carried out at home with online guidance and discussion due to the conditions of Covid-19 which made it impossible to gather. The learning project that is designed is to create a learning media for beginning reading for elementary school students. Wallas' creative process includes 5 stages: preparation, incubation, intimacy, illumination and verification. Distance learning projects are carried out in 7 stages, namely: (1) formulating learning outcomes, (2) understanding concepts, (3) skills training, (4) designing the project, (5) making the project proposal, (6) executing projects and (7) project report. The results showed that in distance project learning can still be done to train creativity with paying more in accessibility of communication and following the learning stage. KEYWORDS

Creativity; distance learning; covid-19; project based learning
\end{abstract}

\section{INTRODUCTION}

Creative process is unique. The way to shape everyone's creativity is different. Sometimes the same treatment doesn't work well for other people. Students who sit in the same class in the same assignment will have many possible solutions to different problems. With a different process, curiosity has many contributions to creative performance (Hardy III et al., 2017). Curiosity leads to a search process that fosters creative thinking skills.

Creativity is associated with divergent thinking skills and is often associated with gifted students. Gifted students have special abilities in creativity and are supported by thinking abilities and other skills. The accommodation of creative skills for gifted students then becomes the focus of researches which is necessary to explore. Providing appropriate support for creative children's in education is done by tracing children's sociocultural (Glăveanu, 2018), or teacher behavior (Soh, 2017).

In contrast to the supports given to gifted children, schools are accused of being the cause of the loss of children's creativity by providing the same curriculum, learning material, training and outcomes for all students. Schools are considered to be boring places and factories that homogenize individuals with their own uniqueness. In order to achieve work demands that require certain competencies and facilitate evaluation, classroom learning has been labeled as an inadequate process for the development of students' divergent thinking skills. Though learning can be designed to support these skills. The same competence can 
be achieved by paying attention to the development of creativity. Many studies have shown that creativity support in the classroom can be done, one of which is belong to (Ritter \& Ferguson, 2017) who conducted a study and found that happy music has an effect on both divergent thinking skills and happy creativity, or (Tan et al., 2016) who found that classroom context matter at the same time emphasized that high-risk exams can help students develop their creativity.

Learning in Indonesia since the launch of the 2013 curriculum (K13) has further strengthened the scientific approach. The learning process is carried out by a series of activities to observe, ask, conduct experiments or seek information, make reasoning or associations to process information and develop networks or communicate the results of investigations (Sani, 2014). This approach is used so that students are able to construct their own knowledge (Ellizar et al., 2018).

In scientific learning, students are trained to be able to carry out higher order thinking processes. The five main stages in this learning are observing, questioning, reasoning, trying and creating networks. This stage is expected to improve students' thinking skills. The learning process using the teacher center is starting to be abandoned, replaced with activities that are in accordance with the scientific process. Variations of learning carried out can use problem-based learning, inquiry, project learning and others.

Project-based learning is assessed according to the K13 learning design. This learning prioritizes the inquiry process, as well as working collaboratively to research and create projects that reflect their knowledge (Bell, 2010). The combination of these three activities leads to the formation of creativity. Having thoughts and actions that give rise to an adaptive product becomes a measuring point (Lubart, 2001) which is claimed to be achieved using the scientific approach (Rudyanto, 2016).

Individual creativity can be shaped by project learning (Gong \& Xin, 2019). Creating a project that requires careful preparation, proper problem analysis, utilizing existing resources in the hope of creating a product, either in the form of ideas or something concrete, trains students' skills in thinking and being creative. Project learning activities make students more professional and closer to real realistic conditions (Trishchenko, 2018). This condition occurs because in project learning, students generally work by means of inquiry. They actively seek out the problems they need to solve by relying on their creativity to find an adaptive and transferable solution.

How to know the formation of creativity through project learning should be explored further in the learning process. The seven stages (Setiawan \& Takaoka, 2020) in project learning cover (1) formulating the expected learning outcomes, (2) understanding the concept of the materials, (3) skills training, (4) designing the project theme, (5) ) making the project proposal, (6) executing the tasks of projects and (7) presentation of the project report. Maximizing the formation of creativity means understanding each learning process, giving extra support and attention to important parts that contain the creative process.

Knowing Wallas' five creative processes are accommodated in project learning helps in understanding how creativity can be trained through this learning. Maximizing student creativity can be achieved by designing learning in accordance with the stages of developing creativity. Each stage is unique and different. The initial and final stages of the creative process are conscious processes that are obtained from the results of objective thinking in finding solutions to problems, while the rest are unconscious processes (Briones, 2020).

Are all conscious and unconscious processes in the creative process well accommodated in project learning? And how can project learning help develop creativity in terms of the 
process that occurs during learning? The demand for distance learning, the effect of the ongoing pandemic in Indonesia, raises more complex questions about how the creative process occurs in project-based learning carried out on distance learning.

Distance learning in situations that are not fully prepared with limited facilities, infrastructure and the ability of teachers, students and parents creates many new problems. Anxiety, boredom, lack of guidance, deposits of assignments that have accumulated to replace learning materials have been complained by many students during distance learning. Writing a paper or answering a series of written questions adds to students' boredom and stress levels. It takes a learning process that does not give excessive pressure, is monotonous and makes students feel more bored staying at home. This learning must also be able to accommodate the needs of students in developing so that learning does not lose its essence.

The aspects of learning needed thus must include cognitive, affective, psychomotor, skills and keep paying attention to the fun, challenging and joyful parts of students. Creativity is an option that can be taken because it is included in higher-order thinking skills and is a skill that is needed in this century. Solving ever-evolving problems requires good creative skills. Practicing it in distance learning is a challenging option to try.

This study offers an investigation of how the project based learning process in distance learning and how to maximize creativity by using project based learning in distance learning. Knowing the learning process and its suitability with the stages of creative formation will facilitate variations and modification of learning.

\section{METHOD}

This research was conducted on grade 2 nd elementary school teacher education students. A total of 40 students attended the same lesson, but only 10 were selected as research subjects considering the depth of information to be extracted and the limitations of the researcher. The object of research is the creative process that occurs when carrying out a learning project.

The learning project is designed using the seven steps (Jalinus et al., 2017), consisting of: (1) formulating the expected learning outcomes, (2) understanding the concept of the teaching materials, (3) skills training, (4) designing the project theme, (5) making the project proposal, (6) executing the tasks of projects and (7) presentation of the project report.

Data were collected using semi-structured observation and interviews. The implementation of learning and data collection is carried out online because the pandemic case in Indonesia has not yet made learning possible in the classroom. The creative process was observed using the five stages of Wallas (Sadler-Smith, 2015), namely preparation; incubation; intimation; illumination; verification. The results of observations and interviews were analyzed and presented descriptively qualitatively.

\section{RESULTS}

Project based learning was conducted in 4 online meetings with seven stages.

Table 1. Seven Stages of Project Based Learning

\begin{tabular}{lll}
\hline No & \multicolumn{1}{c}{ Stages } & \multicolumn{1}{c}{ Activities } \\
\hline $\mathbf{1}$ & $\begin{array}{l}\text { Formulating the } \\
\text { expected learning } \\
\text { outcomes }\end{array}$ & $\begin{array}{l}\text { The expected result is producing a learning media for } \\
\text { beginning reading for elementary school students. From } \\
\text { this main objective it is derived into several learning } \\
\text { objectives, namely: }\end{array}$
\end{tabular}


1) Students are able to formulate problems faced by students when reading the introduction

2) Students are able to build media designs that are in accordance with the problems and potentials that exist in the environment

3) Students are able to develop media designs that they have conceptualized

4) Students are able to use the media they have created 50 students are able to publish their work

2 Understanding the Conduct learning and discussions with students about concept of the teaching materials

3 Skills training.

reading for beginners and their problems

1) Train students to be able to teach how to read for beginners.

2) Introducing students to various learning media

3) Train students to make media designs and their development

4 Designing the project Develop a learning media model design according to the theme problem and consider the availability of materials and the complexity of making

5 Making the project Propose designs and conduct discussions proposal

6 Executing the tasks of Looking for materials and making media according to the projects agreed design in the discussion process. Perform media modifications as needed.

7 Presentation of the Use the product then upload it on an online media project report

The way to find out the creative process involved in learning is to observe the entire series of lessons. The following is a table of student activities related to Wallas' creative process.

Table 2. Wallas' Creative Process

\begin{tabular}{lll}
\hline No & \multicolumn{1}{c}{ Process } & \multicolumn{1}{c}{ Student's Activities } \\
\hline $\mathbf{1}$ & Preparation & $\begin{array}{l}\text { Receive material, gather information, find problems, } \\
\text { practice various media development skills } \\
\text { Take place during the learning break with other } \\
\text { activities or inactivity }\end{array}$ \\
2 & Incubation & $\begin{array}{l}\text { Ideas emerged and were followed up by opening } \\
\text { discussion sessions with colleagues, students and } \\
\text { supervisors }\end{array}$ \\
$\mathbf{3}$ & Intimation & $\begin{array}{l}\text { Creating designs, discussions, gathering materials, } \\
\text { developing products } \\
\text { Try out the media, make modifications, do } \\
\text { publications }\end{array}$ \\
\hline
\end{tabular}

\section{DISCUSSION}

Wallas' stages are seen in project learning in distance learning. The process of creativity occurs from the first stage of learning, namely determining the learning objectives until the publication process. Preparation occurs when (1) the formulating the expected learning 
outcome, (2) understanding the concept of the teaching materials (Mardianti et al., 2018), (3) skills training. Incubation and intimation are not observed in the learning process and are only marked by not continuing the learning process. Illumination occurs when (4) designing the project theme, (5) making the project proposal, (6) executing the tasks of projects. The verification stage occurs when (6) executing the tasks of projects and (7) presentation of the project report.

The stages that are observed during the learning process are at the beginning and final stages of the creative process. The incubation and illumination stages are obtained not during the learning process, they are carried out in a structured manner with the guidance of the lecturer. The initial stage is designed by determining concrete problems that occur and are related to the lecture material. The final objective of learning which is determined at the beginning helps students determine the direction of the process they will go through. Students prepare themselves for the problems given by collecting various information either from the lecturer or independently from various media. By determining learning objectives and communicating them at the beginning of learning, it accelerates the thinking process of students in finding solutions that they will offer.

The two creative processes in the middle are concerned with brain performance functions that cannot be observed and determined in physical activity. This process takes place outside of distance learning hours. Interviews show that there are several variations of activities (Goslin-Jones \& Richards, 2018) in the process of incubation and intimacy. Students stated that the idea was obtained when doing routine activities at home, helping siblings to study, some are not doing any activity (Shetkar et al., 2019), and doing online activities.

Each student has different habits and tendencies in thinking. The incubation process actually took place between lectures when they were doing other activities. In accordance with their daily habits, this process takes place with various periods and activities. This can be seen from the weight of intimacy and different ideas for each student. Are the incubation and intimacy processes related to the level of creativity? No, in this project there is no significant difference between the incubation and intimacy periods. What seems to be very influential is their knowledge of the problems and the projects they will be working on. Students with a higher level of knowledge and master a variety of information related to the project they are working on tend to have more varied, new and interesting thoughts. This can happen because they can make modifications appropriately from a variety of existing information. In contrast to students who do not have sufficient knowledge, they will have difficulty finding problem ideas that have been formulated at the beginning of the lesson. Thus, ensuring that the information gathering stage at the preparation stage (Sitorus, 2016) is met properly accelerates the creative process at the next stage.

The difference in the creative stages in distance learning is the intensity of communication that cannot be done directly. However, the data show that the process and product of creativity can still be carried out with structured mentoring and clear objectives. The key to success in remote creative process guidance is intense communication so that discussions can continue well. Discussion serves to oversee the creative process, provide motivation and foster students' confidence so that they believe that they are able to find a solution that fits the problems they have formulated. Discussions are also useful for accelerating a directed creative process. Clarifying the potential according to the problem makes it easier to form a product at the final stage of creativity.

Lecturers have a big role in guiding students' creative processes. Knowing the creative stages, here using Wallas' creative process, and adapting it to the objectives and learning design has a good influence on student creativity. Providing freedom of thought and 
exploration encourages more creative ideas. What is more important is to formulate an evaluation in accordance with the development of creativity. Paper based tests are not used to encourage students to focus on the project they will complete. This also ensures that memorizing materials or concepts is no longer needed and emphasizes how students are able to come up with new ideas but are right for the problem. The formation of creative ideas is based on a neurocognitive process consisting of retrieval, integration / simulation and evaluation (Benedek, 2018). The cognitive process will run when there is appropriate information input.

The completion of the project shows that students are able to fulfill the learning objectives at the beginning of the lecture. Lecturers guiding at every stage from preparation to publication. The project progresses according to the learning plan successfully carried out with thorough learning preparation, provision of material, stimulation and motivation that challenges students' curiosity and creative power. Raising student curiosity at the beginning of learning plays an important role in encouraging the growth of ideas. Good problems are formulated according to conditions in the community, familiar, they often encounter, and really have to be resolved as soon as possible. Determining problems that do not seem too strange or out of reach of students contributes well to their enthusiasm for processing the expected solutions. At an advanced level, the problem may include something completely beyond the reach of students, but practicing creativity should start with something that is familiar and not burdensome to their thought process. Tasks that are too difficult and seem impossible to complete are not recommended at the basic level of practicing creativity

The learning media has shown the criteria for creative products namely novelty, flexibility, and plausibility (Hakim, 2019), so this method can be tried in learning with the aim of increasing student creativity in the future. Each student needs a different time in the creative process, to see maximum results a reasonable time span is made for project completion. A project that is hastily executed can be guaranteed to only take existing solutions without providing any useful novelty for problem solving. Providing aditional time for students can be done so each student can go through every necessary process without any pressure that really turns off their creative ideas.

\section{CONCLUSION}

Project based learning can be used to practice creative skills. The seven learning stages correspond to Wallas's creativity stage. However, two creative processes, namely incubation and intimacy, do not occur during the learning process. Several variations of activity were observed in this cognitive process. The final result of the project is in accordance with the problems and objectives set at the beginning of the lesson. The success of distance learning projects can be achieved by quality communication with peers and supervisors.

\section{REFERENCES}

Ardhyantama, V. (2020). Pengembangan Kreativitas Berdasarkan Gagasan Ki Hajar Dewantara. Jurnal Pendidikan Dan Kebudayaan, 5(1), 73-86. https://doi.org/10.24832/jpnk.v5i1.1502

Benedek, M. (2018). The neuroscience of creative idea generation. In Exploring Transdisciplinarity in Art and Sciences (pp. 31-48). Springer.

Bell, S. (2010). Project-Based Learning for the 21st Century: Skills for the Future. The Clearing House: A Journal of Educational Strategies, Issues and Ideas, 83(2), 39-43. https://doi.org/10.1080/00098650903505415

Briones, R. P. (2020). Creativity: A Learning Process as Seen from the Perspective of a Free 
Energy Principle. International Journal of Innovation Scientific Research and Review, 2(3), 151-154.

Ellizar, E., Hardeli, H., Beltris, S., \& Suharni, R. (2018). Development of Scientific Approach Based on Discovery Learning Module. OP Conference Series: Materials Science and Engineering, 12101.

Glăveanu, V. P. (2018). Educating which creativity? Thinking Skills and Creativity, 27, 2532.

Gong, H., \& Xin, X. (2019). Buzz and tranquility, what matters for creativity? A case study of the online games industry in Shanghai. Geoforum, 106, 105-114.

Goslin-Jones, T., \& Richards, R. (2018). Mysteries of creative process: Explorations at work and in daily life. In The Palgrave Handbook of Creativity at Work (pp. 71-106). Springer.

Hakim, W. (2019). Penalaran kreatif siswa SMP dalam menyelesaikan masalah sistem persamaan linier dua variabel. SKRIPSI Mahasiswa UM.

Hardy III, J. H., Ness, A. M., \& Mecca, J. (2017). Outside the box: Epistemic curiosity as a predictor of creative problem solving and creative performance. Personality and Individual Differences, 104, 230-237.

Jalinus, N., Nabawi, R. A., \& Mardin, A. (2017). The seven steps of project based learning model to enhance productive competences of vocational students. International Conference on Technology and Vocational Teachers (ICTVT 2017).

Lubart, T. I. (2001). Models of the creative process: Past, present and future. Creativity Research Journal, 13(3-4), 295-308.

Mardianti, I., Masriyah, M., \& Wijayanti, P. (2018). Students' Creative Thinking Process based on the Wallas Stage in Solving Mathematical Modeling Problems. Mathematics, Informatics, Science, and Education International Conference (MISEIC 2018).

Ritter, S. M., \& Ferguson, S. (2017). Happy creativity: Listening to happy music facilitates divergent thinking. PloS One, 12(9), e0182210.

Rudyanto, H. E. (2016). Model discovery learning dengan pendekatan saintifik bermuatan karakter untuk meningkatkan kemampuan berpikir kreatif. Premiere Educandum: Jurnal Pendidikan Dasar Dan Pembelajaran, 4(01).

Sadler-Smith, E. (2015). Wallas' four-stage model of the creative process: More than meets the eye? Creativity Research Journal, 27(4), 342-352.

Sani, R. A. (2014). Pembelajaran saintifik untuk implementasi kurikulum 2013. Bumi Aksara.

Setiawan, A. H., \& Takaoka, R. (2020). Designing PBL steps in vocational course based on students' readiness and teachers' discussion. Journal of Physics: Conference Series, 1456(1), 12045.

Shetkar, R. M., Hankey, A., Nagendra, H. R., \& Pradhan, B. (2019). Association between cyclic meditation and creative cognition: Optimizing connectivity between the frontal and parietal lobes. International Journal of Yoga, 12(1), 29.

Sitorus, J. (2016). Students' creative thinking process stages: Implementation of realistic mathematics education. Thinking Skills and Creativity, 22, 111-120.

Soh, K. (2017). Fostering student creativity through teacher behaviors. Thinking Skills and Creativity, 23, 58-66.

Tan, L. S., Lee, S. S., Ponnusamy, L. D., Koh, E. R., \& Tan, K. C. K. (2016). Fostering creativity in the classroom for high ability students: Context does matter. Education Sciences, 6(4), 36.

Trishchenko, D. A. (2018). Experience of project-based learning: An attempt at objective analysis of results and problems. The Education and Science Journal, 20(4), 132-152. 